\title{
DIE TERREIN, TAAK EN PERSPEKTIEWE VAN DIE TOEGEPASTE WISKUNDE.
}

(Inougurele rede van prof. dr. W. P. ROBBERTSE, Feb. 1950).

Hooggeleerde Rektor,

Hooggeagte Here Lede van die Raad van ons Inrigting, Hooggreleerde Here Professore, Dames en Here Lektore,

Dames en Here Studente,

Dames en Here,

'n Raadpleging van die jaarboeke van ons Suid-Afrikaanse Universiteite magr die indruk laat ontstaan dat onder die Toegepaste Wiskunde alleen die Klassieke Meganika verstaan moet word. Hierdie indruk is verkeerd; dié vakwetenskap sluit veel meer in. 'n Nadere aanduiding van die terrein van die Toegepaste Wiskunde kan egter nie onmiddellik gebeur nie, aangesien dit mede bepaal word deur die terreine van ander vakwetenskappe, maar meer bepaald dié van die Suiwer Wiskunde en die Natuurkunde (Fisika); maar ook van die Fisiese Skeikunde.

Die Toegepaste Wiskunde staan wat sy terrein betref min of meer tussen die Wiskunde en die Natuurkunde; let wel: ons sê: min of meer. Ons kan dan deur die grense van die terreine van én die Wiskunde én die Natuurkunde as vakwetenskappe te bepaal, kom tot die grense van die Toegepaste Wiskunde insoverre as wat hier van grense sprake is. Dat hier van geen skerpe skeidslyne sprake kan wees nie, volg al dadelik daaruit dat die een vak m.b.v. die ander opgebou is.

As ons aan die Suiwer Wiskunde dink dan het ons in gedagte 'n wetenskap wat hom besighou o.a. met getal, hoeveelheid, ruimte, meetkunde en ook meer abstrakte begrippe van orde en analoge tipes van suiwer logiese verbande. Die objektc waarmee die Suiwer Wiskunde werk is alleen die getal en die ruimte. Voorts: al die begrippe en verbande waarvan hier sprake is, is abstraksies; hulle staan los van enige fisiese instansie of entiteit.

As die matematikus sê dat 3 plus 4 gelyk is aan 7 , dan staan die 3 of die 4 of die 7 , nie vir boeke, studente, huise of dergelike entiteite uit ons fisiese wêreld nie. Ons het hier 'n konstatering van 'n verband tussen drie groepe van „dinge," wat abstraksies is, losgemaak van enige besondere fisiese entiteit. Wanneer daar gespreck word van 'n $x$, 'n $y$, 'n 2 of 'n 3, dan word daarmee dus bedoel matematiese groothede uit die matematiese wesensgebied (mathematical reality; vergelyk: physical reality=fisiese wêreld). Oor hierdie gebied bestaan daar, wat sy aard en wese betref, 
uiteenlopende beskouings. Ons wil hier nie daarop ingaan nie. Dis genocg as ons opmerk dat ons in hierdie grebied beweeg in die sfeer van algehele en absolute abstraksie, volkome los van elke partikuliere fisiese entiteit. "The point of mathematics," aldus Whitehead, ,is that in it we have always got rid of the particular instance, and even of any particular sort of entities." En verder: „Mathematics is thought moving in the sphere of complete abstraction from any particular instance of what it is talking about." 1). Of, aldus D. J. van Rooy: „Die Wiskunde is in 'n hecl bepaalde $\sin$ 'n vrye skepping van die menslike gees en as sodanig laat dit hom alleen bind deur die beperkinge waaraan die menslike gees en denke self onderworpe is. 'n Prikkel van buite, 'n praktiese eis kan die sluis van die wiskundige gedagtstroom ooptrek, maar dit kan dit in sy loop nie blywend bepaal, nog minder keer nie. Die wiskundige denke het sy eie wette en sy eie bekoring. Soos die fantasie in onbelemmerde vlug bo die werklikheid uitstyg, ontruk die Wiskunde hom aan die wêreld van konkrete dinge om in die ryk van begrippe ontledend, generaliserend en skeppend te werk te gaan." 2)

Gewoonweg word byvoorbeeld aangeneem dat die eksaktheid van die Wiskunde ' $n$ waarborg is vir die -juistheid van ons meetkundige kennis van die ruimte van ons fisiese wêreld. Die opvatting is verkeerd. Daar is verskillende soorte Meetkunde, soos welbekend is, elke soort opgebou uit 'n groep fundamentele aksiomas. Gaan ons bv. uit van die aksiomas van Euklides, dan kom ons tot die paraboliese vorm van die Meetkunde, waarvolgens (om nou maar 'n bekende resultaat te noem) die som van die hoeke van ' $n$ driehoek gelyk is aan 180 grade.

Neem ons egter die aksiomas van Riemann aan, dan ontstaan daaruit die Elliptiese Meetkunde, waarvolgens nou die som van die hoeke van 'n driehoek groter is as 180 grade. Gaan ons tenslotte uit van die aksiomas van Lobatchevski, dan kom ons tot die Hiperboliese Meetkunde, waaruit volg dat die som van die hoeke van 'n driehoek kleiner is as 180 grade.

As die matematikus dan sê dat die ruimte eindig is en besig on uit te sit (expanding), dan bedoel hy maar net dat die ruimtelike verbande beter pas in een bepaalde wiskundige patroon as in ' $n$ ander en dat die logiese ontwikkeling van hierdie patroon lei tot die gevolgtrekking dat ruimte eindig is en dat dit uitsit.

Die Suiwer Wiskunde is ' $n$ aksiomatiese wetenskap. In die reël bestaan daar 'n algemene analogie tussen hierdie aksiomas en daardie eienskappe en verbande wat volgens ons beste wete vir die besondere

1) A. N. Whitehead: Science and the Modern World, bls. 34 .

2) D. J. van Rooy: „Beginsels en Metodes van die Hoër Onderwys” saamgestel onder redaksie van J. Chr. Coetzee en D. J. van Rooy, bls. 253. 
dinge deur ons waargeneem in die fisiese wêreld, geld. Ons waarneming is egter steeds onderhewig aan fout. M.a.w. ons twyfel aan die absolute juistheid of noukeurigheid van ons waarnemings; tog kan ons die ooreenkoms tussen die deur ons waargenome toestande of verskynsels met een of ander groep suiwere abstrakte voorskrifte of voorwaardes vereenselwig. So kan die aksiomas van 'n bepaalde soort Meetkunde dus gesuggereer word deur ons waarneming van 'n bepaalde groep objekte en verbande uit ons fisiese wêreld. Tog is dit geen waarborg dat die aksiomas van die bepaalde soort Meetkunde vir die waargenome groep objekte en verbande geld nic. M.a.w. so 'n Meetkunde sal dus 'n beskrywing gee wat op sy beste gebrekkig is, van ' $n$ gedeelte van die matematiese wesensgebied, maar nie van ons fisiese wêreld wat aan tyd en ruimte gebonde is nie.

Vervolgens die vraag: Wat is Natuurkunde en wat is die terrein van die Natuurkunde? Natuurkundiges is dit oor die algemeen eens dat hierdie vakwetenskap beskou mag en moet word as 'n studie van materie en energie. Die objek van die Natuurkunde is dus ons fisiese wêreld. M.a.w. die natuurkundige wil 'n beskrywing gee van hierdie wêreld met al sy wetmatighede deur gebruik te maak van alle middels wat hom van diens kan wees. Daartoe beskik hy oor twee hoof metodes nl. die eksperimentele en die teoretiese. Hierdie metodes bepaal vir 'n deel ook die terrein wat die Natuurkunde bestryk.

Vir die ontwerping en konstruksie van sy delikate en ingewikkelde instrumente betree die eksperimentele natuurkundige die gebied van die tegniek. Die teoretiese natuurkundige, wie se doel dit is om die resultate verkry deur waarneming en eksperiment, te koördineer om 'n samehangende beeld van die fisiese wêreld te vorm, moet gryp na die Wiskunde en die Teoretiese Megranika as hulpmiddels. Laasgenoende proses is wat die afbakening van dic terrein van dic Toegepaste Wiskunde betref van groot belang. Daarop wil ons dieper ingaan, maar eers wil ons die terrein van die Toegepaste Wiskunde in breë trekke aandui.

Oor wat teenswoordig onder Toegepaste Wiskunde verstaan moet word bestaan daar blykbaar nie oral ooreenstemming nie.

Een opvatting is blykbaar dat dit Wiskunde gerig op toepassing is; let wel: nie Wiskunde toegepas nie. So word in een van die jongste Amerikaanse publikasies deur F. D. Murnaghan onder die titel "Introduction to Applied Mathematics" die volgende onderwerpe hehande!: Vektore en Matrikse, Lineêre Vektor-funksies, Funksic-vektore, Fourierreekse, ens. Hierdie beskouing word ook vry algemeen op die Europese vasteland gehuldig. 
'n Volgende opvatting wil dat ons van Toegepaste Wiskunde kan spreek sodra aan 'n wiskundige simbool 'n fisiese betekenis gegee word. Volgens dié beskouing word dit dan Wiskunde toegepas.

Die tradisionele Britse standpunt is dat onder Toegepaste Wiskunde alleen die sogenaamde Klassieke Meganika verstaan moet word. Hierdie beskouing dateer ongeveer vanaf die tyd van Newton, toe hy sy beroemde „bewegings"-wette geformuleer het. Uit hierdie wette het die hele gebou van die Klassieke Meganika ontwikkel. Dit het toe bekend gstaan onder die vakwetenskaplike naam „Applied Mathematics." Teenswoordig sluit die naam in Brittanje veel meer as net die Klassieke Meganika in; ook die Moderne Meganika en nog meer. Ons wil hierdie standpunt handhaaf.

Onder Toegepaste Wiskunde wil ons dus verstaan: Meganika, sowel die Klassieke as die Moderne; en meer bepaald wil ons op sy beurt hieronder verstaan: bewegingsleer. Ons betree hier dus die gebied van dic sogenaamde energetiek.

Dic naam Toegepaste Wiskunde is dus misleidend en beklee die ere-posisie alleen terwille van die tradisie.

Soos reeds genoem is die objekte van die Suiwer Wiskunde die getal en die ruimte. Die Meganika voer,-behalwe hierdie twee, nog twee nuwe objekte in nl. massa en tyd. Die getalle-kontinuum en die objek tyd leen hulle tot onderlinge vereenselwiging.

Hierdie nuwe objekte van massa en tyd word voorasnog nie gedefinieër as of vereenselwig met bepaalde fisiese entiteite nie. Hulle leen hulle wel daartoe. Deur die invoering van hierdie twee nuwe objekte of grondbegrippe tree ons vanaf die Suiwer Wiskunde 'n stap nader aan die Natuurkunde. Die Meganika beskik oor meer middels on die Natuurkunde te steun, juis omdat hierdie objekte vereenselwig kan word met entiteite uit die fisiese wêreld.

Dic Klassieke Meganika is opgebou o.a. met behulp van die bewegingswette van Newton en sy algemene swaartekragswet, gebruikmakende van die objekte van die Suiwer Wiskunde en van massa en tyd.

Die drie bewegingswette lui soos volg:

1) 'n Liggaam wat nie die werking van kragte ondergaan nie, is in rus of beweeg gelykmatig langs 'n reguit lyn.

2) Die groeitempo van die momentum van 'n massa is eweredig met die krag wat daarop werk.

3) Aan elke aksie is daar ' $n$ gelyke teëgestelde reaksie.

Indien hierdie wette, tesame met die enkele andere 3) waaruit die

3) Hier word bedoel:

(a) die parallelogram-wet;

(b) die verskuifbaarheid van 'n krag langs sy werklyn vir 'n rigide liggaam;

(c) dat twee gelyke teëgestelde kragte mekaar ophef. 
Meganika opgebou is, aanvaar word as aksiomas, dan kan die Meganika beskou word as 'n uitbreiding van die Suiwer Wiskunde, as ons daarby onthou dat:

(I) die objek tyd met die getalle-kontinuum vereenselwig kan word (II) massas, soos Poincaré tereg opmerk, 4) koeffisiënte is wat gerieflikheidshalwe ingevoer word.

Die Natuurkundige sal onmiddellik beswaar maak teen so 'n beskouing want hy sien graag die Meganika as 'n onderdeel van die Natuurkunde, meer bepaald as 'n onderdeel van die Teoretiese Natuurkunde. Vir hom is hicrdie wette eksperimentele waarhede. Die Meganika staan m.a.w. op die brug tussen die Suiwer Wiskunde en die Natuurkunde.

Ons het hier probeer onderskei, nie om te skei nie. Laasgenoemde is onmoontlik. Die toestand is daarvoor op die oomblik te vloeibaar. Die Wiskunde, Meganika en Natuurkunde sit innig in mekaar vervleg; bowedien vind daar so 'n gedurige wisselwerking plaas, dat van 'n absolute skeiding van terreine hier nie gespreek kan word nie. Die terrein van die Suiwer Wiskunde, sou ons sê, kan die suiwerste afgebaken word.

Ons het vroeër opgemerk dat veral die Teoretiese Natuurkunde die Wiskunde en Meganika as hulpmiddels gebruik, en pas het ons gespreek van 'n innige vervlegting van hierdie wetenskappe. Laat ons hierdie bewerings nader ondersoek. Dit sal meteen meer lig werp op die terrein van die Eksperimentele en die Teoretiese Natuurkunde en die Meganika. Meer nog, dit sal aan ons ' $n$ besondere taak van die Meganika toon. Die eksperimentele navorser versamel sy gegewens deur waarneming en eksperiment. Daarby is hy steeds bewus dat sy waarneming alleen die werklikheid benader. Hy neem aan dat 'n sekere verskynsel die produk van bepalende faktore is en dat dieselfde faktore steeds dieselfde verskynsel moet veroorsaak. Uitgaande van hierdie gedagte probeer hy die verskynsel reproduseer. Al sy waarnemings en bevindings word opgeteken met die doel om te kom tot kwantitatiewe betrekkings tussen die bepalende omstandighede en gevolg. In kort, dit is sy taak on die fisiese gegewens te kwantifiseer.

Die betrekkings wat langs hierdie weg opgespoor word, word opgeteken as empiriese wette. Ter formulering daarvan word die hulp van die Wiskunde en die Meganika ingeroep-gerieflikheidshalwe-; terwille van die oorsigtelikheid en saaklikheid.

Hierdie empiriese wet is nie genoeg nie. Ons moet kom tot 'n generalisasie. Immers: die eksperiment is individueel, ons soek na 'n

4) H. Poincaré: The Foundations of Science, bls, 102. (Vertaling deur G. B. Halsted). 
algemene wet; die eksperiment gee 'n benadering, ons soek na 'n eksakte betrekking; die eksperiment word uitgevoer onder 'n reeks komplekse voorwaardes en omstandighede, ons wil dié faktore uitskakel.

Hoe moet nou die eksperimentele resultate en die empiriese wette gebruik word om tot 'n generalisasie te kom? Weer is dit én die Wiskunde én die Meganika wat in die bres tree. Immers, dit is Hierdie wetenskappe wat abstraheer, wat vorm hanteer en nie materie nie. So is dit bv. die Meganika wat aan snelheid, versnelling en die veldkrag in 'n punt van 'n potensiaalveld die naam vektor toeken.

Die volgende voorbeeld illustreer die hele proses nog mooier: In die loop van sowat 20 jaar het Tycho Brahe bloot deur waarneming massas gegewens i.v.m. die planete-bewegings versamel. Hieruit kon Kepler sy drie empiriese wette aflei. Dit het egter 'n Newton gekos on op sy beurt daaruit sy beroemde omgekeerde vierkantswet-'n natuurwet en dié fundamentele wet van die meganika van die sonnestelsel-af te lei.

Die Teoretiese Natuurkundige sal seker wil beweer dat dit sy terrein is hierdie: om te abstraheer, wette te formuleer en te koördineer.Ons het geen beswaar daarteen nie, immers die wetenskappe sit hier so vervleg dat ons nie kan skei nie, slegs onderskei. Vir die beoefenaar van die Meganika, egter, bly dit die taak van die Natuurkunde om hom te voorsien van kwantitaticwe gegewens (die werk van die eksperimentele natuurkundige) en voorts van wette en teorië (die werk van die teoretiese natuurkundige) met die afleiding waarvan dit self behulpsaam wil wees, oin sy gebou op te rig. Hierdie gebou word ontwerp en opgerig mede vir die Natuurkunde, om hom te help om sy resultate tuis te bring d.w.s. te koördincer en elkeen sy beskeie plek in die geheel toe te wys. Maar meer nog, dit wil die Natuurkundige help om vooruit te sien, om sy navorsing so te rig dat die grootste opbrengs vir die wetenskap gewaarborg word.

Laat ons die hele probleem vanuit 'n ander gesigspunt benader. Reeds het ons gemeld dat die doel van die ondersoek is om tot 'n generalisasie te kom. Elke generalisasie impliseer op sy beurt ' $n$ samehang, meer nog, 'n eenheid van ons fisiese wêreld - die verskillende dele is soos die ledemate van een liggaam. Die navorser wil dan die samestelling van die geheel ontleed. Sy ondersoek rig hy om uit die hele kompleks van natuurverskynsels die elementêre samestellende verskynsels te onderskei en te ondersoek. Slaag hy daarin is dit eenvoudig om verder te gaan m.b.v. van die Meganika en die Wiskunde.

Ter opsporing van die elementêre verskynsels kan ons cen van drie metodes aanwend: 
(i) Ons ontleed dic verskynsels in die tyd: In plaas daarvan om die verskynsel meteen in sy geheel, in sy voortgang en ontwikkeling in die tyd te probeer oorsien, word elke oomblik afsonderlik beskou en met die oomblik wat onmiddellik daaraan voorafgaan, verbind. Die uitgangspunt hier is naamlik dat die stand van ons fisiese wêreld op 'n bepaalde tydstip regstreeks alleen afhanklik is van die oomblik wat dit voorafgaan, sonder dat dit deur 'n afgeleë verlede onmiddellik beinvloed word. Danksy hierdie waarheid kan ons die verloop van verskynsels bestudeer aan die hand van, om Wiskundige taal te gebruik, differensiaalvergelykings. So word bv. die wette van Newton gesubstitueer vir die van Kepler.

(ii) Tweedens analiseer ons die komplekse verskynsel in die ruimte. Wat die eksperiment ons gee, is 'n ongeordende massa feite, uitgestal op ' $n$ verhoog van taamlik breë omvang. Nou word gepoog om die elementêre verskynsel wat omgekeerd, gelokaliseer is in 'n bepaalde element van die ruimte, te ontdek. 'n Voorbeeld mag help om die gedagtegang te verduidelik.

Veronderstel dat ons die temperatuursverspreiding in 'n afkoelende liggaam wil bepaal. Beskou ons die liggaam in sy geheel dan lei dit ons tot niks. Die probleem word eenvoudiger as ons.bedink dat 'n massadeeltjie sy warmte nie sonder meer regstreeks kan oordra op 'n afgeleë deeltjie nie, maar dat dit oorgedra word op die onniddellik-aangrensende deeltije. So word die warmte van deeltjie tot deeltjie oorgedra. Die elementêre verskynsel waarvan hier sprake is, is dan die voortplanting van warmte tussen twee aangrensende punte. Dit is streng grelokaliseerd en betreklik eenvoudig as ons aanneem dat dié proses nie beinvloed word deur warmte van deeltjies op eindige afstand, ongelyk nul, van die twee betrokke punte nie.

(iii) Derdens kan ons gebruik maak van die wet van die groot getal d.w.s. ons kan statisties te werk gaan om dic elementere verskynsels op te spoor. Dit voer ons terug na die eksperiment.

Wanneer dic elementêre verskynsel geïsolecr is, kan dic saak aan die Meganika en die Wiskunde oorgelaat word, want nou kan die differensiaalvergelyking van die probleem opgestel word. Hierdie proses word miskien makliker begryp as ons opmerk dat elke saamgestelde verskynsel die resultaat is van die superponering van 'n reeks elementêre verskynsels. As elkeen van die saanıgestelde verskynsels in besonderhede ontleed is, kan vir verskynsels wat dieselfde wet gehoorsaam weer oorgegaan word tot superponering om 'n beeld van die resultaat, d.i. die saamgestelde verskynsel te vind. Dit is die taak van die Meganika.

Ons het gepong om die besondere taak te skets wat die Meganika ter ondersteuning van die Natuurkunde by die verwerking van sy gegewens, te vervul het. Die Natuurkunde kwantifiseer fisiese gegewens en lei mei 
die hulp van die Meganika en ook van die Wiskunde, wette af. Die Meganika gebruik hierdie wette as boustowwe om 'n skoon gebou, as ons dit so mag noem, te laat verrys, 'n gebou wat beplan word mede terwille van die Natuurkunde, maar veral terwille van homself. Hierdie wetenskap bied aan die Natuurkunde op sy beurt materiaal vir nuwe ondersoekinge en ontdekkinge. Meer nog, telkens as die (eksperimentele) natuurkunde op resultate stuit wat nie aan die hand van bestaande teorieë en beskouinge verklaar kan word nie, m.a.w. as hy resultate vind wat in die ou gebou nie wil pas nie, dan snel die Meganika met nuwe teorieë en perspektiewe te hulp wat dan die probleem oplos.. Die ontwikkeling van dic Einsteinse Meganika is hiervan die skitterendste voorbeeld

Dic ontwikkeling van die Relativiteitsteorie van Einstein en daarmee die Einsteinse Meganika is een verhaal van onderlinge hulp en bystand tussen Meganika en Natuurkunde; dit is ' $n$ verhaal van die ontwikkeling van nuwe begrippe, teorieë en beskouinge deur die Meganika om aan die Natuurkunde, wat eerste die behoefte gevoel het, 'n nuwe en geskikte basis te bied met behulp waarvan die nuutgevonde resultate wat nie aan die hand van bekende begrippe en teorieë verklaar kon word nie, nou wel verklaar kan word. Trouens, die Relativiteitsteorie van Einstein is 'n logiese uitbouing van die relativiteitsprinsiep van die Newtonse of Klassieke Meganika met hoofsaaklik gewysigde begrippe van tyd en ruimte.

"Tyd" en "ruimte" ontbreek om hierop volledig in te gaan. Ons veroorloof ons slegs enkele opmerkings i.v.m. die Spesiale Relativiteitsteorie.

Die bewegingswette van Newton waarmee ons reeds vroeër kennis gemaak het veronderstel die volgende:

(i) absolute ruimte.

(ii) absolute tyd.

(iii) absolute sekerheid i.v.m. (a) die gelykheid van twee gebeurtenisse en (b) gelykheid van twee tydsdure.

(iv) 'n Euklidiese ruinte d.w.s. 'n Euklidiese maatsbepaling.

Newton het self geskryf: „Absolute motion is the translation from one absolute place to another absolute place." 5). Hy verduidelik egter nie wat hy onder 'n "absolute place" verstaan nie. Voorts verklaar hy: "Absolute, true and mathematical time, of itself, and by its own nature flows uniformly on, without regard to anything external." 6). Hy het dus klaarblyklik aangeneem dat daar 'n enkele tydskaal bestaan wat oral geld.

Hierdie opvattinge bots met sekere resultate verkry uit die elektrodinamiese teorie van lig. Veral lei dit tot teenstrydighede i.v.m. die voortplantingsnclheid van lig in vacuo. Deur aan te toon dat fisiese tyd

5) E. Mach: Science of Mechanics, 4e druk, bls. 226 (1919).

6) Ibid, bls. 222. 
en fisiese ruimte twee relatiewe begrippe is en met die formulering van die twee fundamentele wette van die Spesiale Relativiteitsteorie nl.:

(i) die voortplantingsnelheid van lig in vacuo is onafhanklik van die snelheid van die ligbron.

(ii) die wette van die Natuurverskynsels bly dieselfde wanneer dit geformulcer word m.b.v. enigeen van twee inersiële assesstelsels, kon Einstein sy teorie opbou en aantoon dat hier geen teenstrydigheid bestaan nie. Die Einsteinse Meganika is dan ook nie in botsing met die Newtonse Meganika nie, mits ons in eersgenoemde die snelheid van lig oneindig groot neem d.w.s. as alle breuke waarin die ligsnelheid $\mathrm{c}$ in die noemer voorkom, gelyk aan nul gestel word. Ons val dan terug op die Klassieke Meganika. Laasgenoende is 'n benadering vir cersgenoemde. Dit geld met ' $n$ hoë graad van noukeurigheid vir groot massas, klein snelhede en klein afstande. Voldoende getuienis hiertoe is die byna verstommende noukeurigheid waarmee dit die planete-bewegings met soveel delikate besonderhede beskryf.

Hierdie teorie, wat dan ontwerp en opgebou is met die oog op, en terwille van die oneindige sterrewêreld het nuwe vérgesigte cn perspektiewe geopen vir beide die Meganika en die Natuurkunde. Laasgenoemde het ontsettend veel baat daarby gevind.

Ons sou kon voortgaan en aantoon hoedat die Kwantum- en Golwemeganika hulle ontstaan gevind het. Hierdie twee ekwivalente, maar verskillend geformuleerde teorieë wat ontwerp is vir die oneindige ,atoom-wêreld," dank eweas die Relativiteitsteorie hul oorsprong en ontwikkeling grotendeels aan die beheoeftes van die Natuurkunde. Ons kan hier nie daarop ingaan nie. Genoeg as ons opmerk dat albei „moderne geboue" van die Meganika is. Wat hier egter van groot belang is, is die feit dat die Kwantum- en Golwe-Meganika aan die eenkant en die Relativiteitsteoric aan die anderkant dusver nog steeds onversoend gestaan het. Kort gelede, dit was in Desember van 1949, is in die pers aangekondig dat Einstein 'n nuwe swaartekragsteorie ontwikkel het. Hyself, so lui die berig, noem dit ,'n veralgemening van die swaartekragsteorie" en glo dat hy daarmee daarin geslaag het om die terreine van die swaartekrag en die elektro-magnetisme te verenig. Ons siteer voorts die berig woordeliks: „Einstein se jongste werk wil die laaste gaping oorbrug wat daar lê tussen die oneindige sterrewêreld en die ewe oneindige atoomwêreld. Op die oomblik lê hierdie twee wêrelde ver van mekaar af waar die een deur die Einsteinse Relativiteitsteorie verduidelik word, terwyl ons kennis van die ander berus op die Kwantum-teorie waarvan Einstein ook een van die vernaamste argitekte was." 7).

7) Die Vaderland, 28 Desember 1949, bls. 7. 
As hierdie aankondiging juis is, dan gaan ' $n$ droom van die Meganika in vervulling. 'n Deur gaan oop en nuwe perspektiewe ontplooi hulle, en nuwe vérgesigte word geopen. Hier lê die arbeidsveld van die Meganika vir die hede en die toekoms. Maar genoeg hiervan. Die terrein en die taak van die Toegepaste Wiskunde, sover dit die tegniese aspek betref het ons hiermee volledig genoeg geskets.

Daar is ander aspekte wat ons aandag vra.

Die taak van enige akademiese vakwetenskap hang saam met die taak van die Universiteit. Die taak van laasgenoende, kan volgens $\mathbf{H}$. G. Stoker 8) korteliks soos volg saamgevat word:

1) Wetenskapsbou d.w.s. die ontwikkeling en uitbouing van die wetenskap deur die ontdekking en bekendstelling van nuwe waarhede, die omvorming van en kritiek op bestaande teorieë en beskouinnge, ens.

2) Bewaring (deur oordrag) van die wetenskap. Dit sou o.a. meebring: onderwys aan studente en gemeenskap nie met die oog op beroepe en professies nie, maar terwille van die (a) bewaring van die wetenskap en (b) persoonlikheidsvorming.

3) Vorming en kweking van leiers.

4) Opleiding vir hoër beroepe.

5) Taak (4) loop uit op 'n sosiale handeling wat as die vyfde taak beskou kan word nl. toekenning van grade.

6) Besondere probleme d.w.s. oplossing van probleme waarmee die samelewing te kampe het.

Die Toegepaste Wiskunde het t.o.v. elkeen van hierdie ses punte 'n eie verantwoordelikheid en funksie, soos elke ander vakwetenskap wat aan die Universiteit gedoseer word. Ons doel is nie om by almal stil te staan nie. Enkele aspekte van punt (1) is so belangrik dat ons daaraan nog aandag moet gee.

Tot dusver het ons betoog die lig veral laat val op die terrein en die taak van die Toegepaste Wiskunde wat betref die bou van die eie wetenskaplike huis. Hierdie taak het 'n estetiese en metafisiese aspek wat van groot belang is; die pragmatiese laat ons op die oomblik tersy.

Vanuit 'n estetiese oogpunt het die Meganika en die Wiskunde vir die beoefenaar daarvan eweveel waarde as 'n skildery vir die skilder. Dit is geen losse bewering nie. Immers: waarneming is 'n persoonlikheidsakte waartoe primêr die sintuie, maar ook ander funksies van die persoonlikheid ingespan word. So byvoorbeeld, word waarhede uit die matematiese wesensgebied waargeneem en geken deur die denke. 'n Gevoel van estetiese voldoening vind sy aanleiding dan ook nie uitsluitlik in sintuiglike waarneming nic. Die ontdekker en voltooier van 'n wiskundige stelling

8) Koers: Deel XVII, No. 4, bls. 149. 
of teorie smaak daarvan dieselfde voldoenig as die kunstenaar van sy skildery of as die komponis van die lied deur hom gekomponeer. G. H. Hardy se ganse betoog in sy „A Mathematician's Apology” kom in hoofsaak daarop neer dat hy sy ganse lewe gewei het aan die Wiskunde (a) terwille van die estetiese waarde daarvan vir hom en (b) omdat hy vir niks anders sou deug nie. Hy skryf letterlik: „A Mathematician like a painted or a poet is a maker of patterns ... The (Mathematicians) patterns ... must be beautiful; the ideas like the colours or the words must fit together in a harmonious way. Beauty is the first test; there is no place in the world for ugly mathematics." 9) En verder: „.. . The mathematics which has permanent aesthetic value as for example the best Greek mathematics has, .... continue to cause intense emotional satisfaction to thousands of people after thousands of years." 10) As dit geld vir die Wiskunde, dan eweseer vir die Toegepaste Wiskunde tenspyte daarvan dat dieselfde Hardy beweer dat die beste produkte van die Toegepaste Wiskunde verwerp moet word sodra hulle voltooi is ondat die ontwerpte patroon nie op die feite pas nie. Maar wat van die patrone wat wel pas? Die hele gebou van die Meganika spreek van die teendeel. „Lelike" Toegepaste Wiskunde bestaan vir ons nie, want soos Hardy self sê, beland dit in die snippermandjie.

Toe Kopernicus sy patroon van ons sonnestelsel ontwerp het, 'n patroon wat die een van Ptolemeus moes vervang, het dit in stryd met die destydse gangbare opvatting, die steun van Galileo en Kepler gewen bloot as gevolg van die estetiese bekoring wat die pragtige ontwerp besit het. Later het gebiyk dat sy teorie ook in ander opsigte die voorkeur verdien.

Nog ' $n$ voorbeeld: Toe Clerk Maxwell sy werk i.v.m. elektrodinamika begin het, het die wette wat tot op datum bekend was alle bekende feite verklaar. By 'n nadere beskouing van die elektro-dinamiese vergelykings het sy gevoel vir simmetrie hom nog 'n term laat byvoeg. Hierdie term was so klein dat dit geen betekenisvolle verandering meegebring het t.o.v. die bekende resultate nie. Twintig jaar later is deur eksperiment bevestig dat hy reg was.

Inderdaad: hier het ons iets in die Toegepaste Wiskunde, eweas in die Suiwer Wiskunde, wat hom nie laat besyfer nie. Maar genoeg hiervan, ons wend ons tot die metafisiese aspek.

Soos ons aangetoon het bestryk die Toegepaste Wiskunde in hoofsaak die gebied van die Meganika. Hoewel die naam Toegepaste Wiskunde dus misleidend kan wees, laat dit tog een aspek van hierdie weten-

9) G. H. Hardy: A Mathematician's Apology, bls. 17.

10) Ibid, bls. 24. 
skap in die oogspring, $\mathrm{nl}$. dat dit in essense ' $\mathrm{n}$ Wiskunde is. D.w.s. dit is geen eksperimentele wetenskap nie maar 'n aksiomatiese. Ons het volledig probeer aantoon hoedat ons tot die formulering van natuurwette kom. Die Toegepaste Wiskunde aanvaar hierdie natuurwette as deel van sy aksiomas. Dit is niks ongewoons nie. Baie van die aksiomas van selfs die Suiwer Wiskunde word deur die ervaring gesuggereer.

Dit is egter nie die enigste bron van die aksiomas van hierdie wetenskap nie, soos met meer wetenskappe die geval is. Die navorser begin in die reël met allerlei veronderstellinge te maak, of soos meesal gebeur, hy akseptecr eenvoudig hierdie veronderstellinge onbewus. Hierdie fundamentele hipoteses onderskei hulle van die deur die eksperiment gesugrgereerde hipoteses hierin, dat hulle hul van elke bewysvoering onttrek. Nietemin: uitgaande van hierdie aksiomas word die gebou van die Toegepaste Wiskunde deur aanwending van die wette van die logika gekonstrueer. Dit gee dié wetenskap dadelik 'n aksiomatiese aard asmede 'n filosofiese grondslag.

By die keuse van hierdie aksiomas, en meer bepaald die groep wat aan geen bewysvoering onderwerp kan word nie, sal verskillende faktore 'n rol speel. Die keuse is tot op 'n sekere hoogte willekeurig, maar staan sekerlik mede onder invloed van die lewens- en wêreldbeskouing van die navorser, en dit is hierdie faktor wat ons sterk wil beklemtoon. Immers die fundamentele uitgangspunte bepaal die ganse bowe-struktuur van die wetenskaplike huis. Ons verwys bv. na die drie tipes Meetkunde soos reeds vroeër genoem.

Elke navorser soek na die „waarheid" en nou lê verskillende skole verskillende maatstawwe vir die waarheid aan. Die lewensbelang wat die Christelike navorser by die keuse van die uitgangspunte het, is nou sonder meer duidelik. Wil hy konsekwent wees, meer nog, wil hy sy belydenis nie verloën nie, sal die keuse geskied in die lig van die Goddelike Openbaring in die Heilige Skrif. Hy ken dus aan die Skrif 'n sintestiese, 'n saambouende funksie in sy wetenskapsbeoefening toe.

Gedurende die laaste halwe eeu het daar diepgaande meningsverskille ontstaan oor die grondslae van die Wiskunde. En hierdie stryd laat juis die rol sien wat die uitgangspunt speel.

Dit gaan hier ten slotte om die betroubaarheid van die fundamentele uitgangspunte.

As Kant tyd en ruimte beskou as aanskouingsvorme van die menslike gees, inherent aan sy gees, apriori aan hom gegee, en waarsonder ons van geen enkele ervaring bewus word nie, en as volgens hierdie beskouing verklaar word dat die oorsprong van die meetkundige objekte in die menslike grees setel en hulle grondeienskappe dus onmiddellik intuitief 
duidelik is, d.w.s. as die aksiomas van die Meetkunde dan dié van Euklides is, hoe is dit dan moontlik dat die menslike gees naas die Euklidiese Meetkunde nog verskillende ander Meetkundes verdra as die ervaring ons tot geen keuse dwing nie? Ons laat dit daar.

Vir die intuïsionis is die norm vir die waarheid van sy aksiomas die konstrueerbaarheid daarvan uit die sogenaamde oer-intuissie.

Vir die formalis is die norm die nie-strydigheid van sy aksiomas. Ons laat hierdie kwessies daar en wil slegs saam met J. F. Koksma 11) die vraag stel of al die verskillende aksioma-sisteme (ook die wat ten grondslag van die Toegepaste Wiskunde lê) nie veeleer die karakter van hipoteses dra nie, hipoteses waarmee ons op die „wêreld" om ons afgaan om daarop die apparaat van ons intellek toe te pas, hipoteses wat onderling kan verskil al na gelang die aard van die spesiale ondersoek wat ons besighou. Byvoorbeeld: teneinde 'n beskrywing van sekere natuurgebeure te verkry, stel die fisikus op die een oomblik lig as 'n trilling voor en op die ander oomblik as 'n stroom van klein deeltjies.

Tenslotte bly die vraag dan tog nog: Waarin skuil nou eindelik die waarheid?

By die beantwoording van die vraag beslis die wêreldbeskouing. Hierby kan ons probeer om die verskillende opvattinge wat oor elke besondere vakwetenskap mag bestaan, tuis te bring in die breëre raam van die groot wysgerige strominge en hulle dan vanuit eie wysgerige standpunt te beoordeel. Daartoe is ons nie in staat nie. Volgens ons beskeie mening is dit die terrein en die taak van die vakfilosoof.

Nietemin, die Christelike navorser weet dat hy die volle waarheid nie sal ontdek nie, want ons ken maar ten dele; die volle waarheid sal hy op sy beste slegs kan benader. En mens en natuur is die handewerk van God, die Skepper van hemel en aarde. En nou weet hy: God is 'n God van wet en orde. God het orde in die verskeidenheid geplaas, maar hy het ook die mens behep met die vermoë om daardic „wet en orde" na te speur. Waar Kepler aan Galileo skryf: „Die Raumwissenschaft ist einzig und ewig und strahlt wieder aus dem Geiste Gottes. Dass die Menschen an ihr teil haben dürfen, ist mit einer der Gründe, weshalb der Mensch das Ebenbild Gottes ist," 12) kan ons grotendeels met hom saamstem.

Die wet en orde in die Skepping verstaan die Christelike navorser nie in die sin waarin Laplace met sy meganistiese determinisme dit wil sien nie, ook nie soos 'n Jeans of 'n Eddington wat die onsekerheid wat deel is van ons natuurwette aan die natuur self wil wyt nic, nee, hy

11) J. F. Koksma: Wiskunde en Waarheid, bls. 12.

12) H. Weyl: Philosophie der Mathematik und Naturwissenschaft, bls. 95. 
aanvaar dit dat God die Here die Skepping in aansien geroep het en nog in stand hou, met klem op die laaste sin.

Ten slotte: hy aanvaar sowel Gods Woordopenbaring as die natuur wat hy ondersoek; hy erken die wesenverskil tussen God en sy Skepping, wat daarin uitkom dat God Algenoegsame Wetgewer is wat Sy Skepping aan Goddelike wette onderworpe is. Verder erken hy dat God alleen die Absolute is en sal dus waak teen ' $n$ verabsolutering van sy vak. Hy erken die beginsel van soewereiniteit in eie kring en sal nie toelaat dat sy vak andere probecr oorheers nie." 13)

Hy aanvaar dat God in die natuur 'n samehangende verskeidenheid gelê het, en sal dus nooit hierdic verskeidenheid probeer wegredeneer of tot een verskynsel reduseer nie. Hy weet ook dat sy cie verstand deur die sonde vertroebel is, en as sodanig aan strenge beperkinge onderhewig is. Die menslike denke sal dus nooit onder hierdie bedeling foutloos kan wees nie.

Ek wil by hierdie geleentheid my dank uitspreek teenoor die Raad en die Senaat vir die vertroue in my gestel deur die benoeming tot tweede professor in die Wiskunde en Toegrepaste Wiskunde.

Ook die beoefenaar van dié vakwetenskappe staan voor die keuse om sy wetenskap te beocfen by die Lig van Gods Woord of nie. Om die taak wat aan my opgedra is, uit te voer onder die besieling van die leuse van ons inrigting , "In U Lig" is vir my 'n groot voorreg en stem my tot diepe dankbaarheid.

\section{Hooggeleerde D. J. van Rooy,}

Dit is nog maar cnkele jare gelede wat ck $u$ boeiende kolleges in én die Wiskunde én dic Toegepaste Wiskunde gevolg het. Dat ek my onder $u$ leiding in hierdie vakke kon bekwaam was vir my 'n groot voorreg. Maar meer nog, u prinsipiële leiding in hierdie vakke het sy stempel onuitwisbaar afgedruk ook op my beskouing van hierdie vakke, maar trouens ook op my hele lewensbeskouing.

$U$ het vir my allengs van leermeester tot ' $n$ ouere vriend geword wat ek steeds bereid gevind het om my met raad en daad by te staan. Na u leiding sal ek steeds opsien. U rype ervaring en meerdere kennis kan ons nic ontbeer nie. Dat ek saam met $u$ in die departement waarvan $u$ die grondslae met soveel deeglikheid en deursettingsvermoë gelê het, mag werk, stem my tot groot vreugde, maar ook tot diepe ootmoed.

Dames en here, ek dank u vir u welwillende gehoor.

13) S. J. du Toit:: Koers, Oktober 1944: Calvinisme en Natuurkunde. 